\title{
Democracy and the Environment: How Political Freedom Is Linked with Environmental Sustainability
}

\author{
Elias G. Carayannis ${ }^{1, *}$, David F. J. Campbell ${ }^{2,3,4}$ and Evangelos Grigoroudis ${ }^{5}[$ \\ 1 School of Business, The George Washington University, Washington, DC 20052, USA \\ 2 Department for Higher Education Research, Danube University Krems, 3500 Krems, Austria; \\ david.campbell@donau-uni.ac.at \\ 3 Department of Political Science, University of Vienna, Universitätsstrasse 7, 1010 Vienna, Austria \\ 4 Department of Science Communication and Higher Education Research, Alpen-Adria-University Klagenfurt, \\ 9020 Klagenfurt, Austria \\ 5 School of Production Engineering and Management, University Campus, Technical University of Crete, \\ Kounoupidiana, 73100 Chania, Greece; vangelis@ergasya.tuc.gr \\ * Correspondence: caraye@gwu.edu
}

Citation: Carayannis, E.G.; Campbell, D.F.J.; Grigoroudis, E. Democracy and the Environment: How Political Freedom Is Linked with Environmental Sustainability. Sustainability 2021, 13, 5522. https://doi.org/10.3390/su13105522

Academic Editors: Marco Vivarelli and Marc A. Rosen

Received: 17 March 2021

Accepted: 11 May 2021

Published: 15 May 2021

Publisher's Note: MDPI stays neutral with regard to jurisdictional claims in published maps and institutional affiliations.

Copyright: (C) 2021 by the authors. Licensee MDPI, Basel, Switzerland. This article is an open access article distributed under the terms and conditions of the Creative Commons Attribution (CC BY) license (https:// creativecommons.org/licenses/by/ $4.0 /)$.

\begin{abstract}
This paper aims to explore a possible relationship between democracy and the environment, more specifically between freedom and environmental sustainability (environmental performance). The conceptual lenses of the Quadruple and Quintuple Innovation Helix Frameworks were used as they emphasize the importance of democracy and ecology (environmental sustainability) for knowledge and innovation and vice versa. The empirical model focused on the following research question: What is the correlation between political freedom and environmental performance? In essence, all countries in the world with a population of one million or more were included (a total of 156 countries), and the reference year was 2016. The empirical outcome of the correlation analysis was a positive Pearson correlation of about 0.56 (or 0.73 if we examine regional country groups), and, perhaps even more significantly, this correlation was significant at the 0.001 level (two-tailed). The correlation results lend themselves to the following interpretation: The higher the political freedom in a country, the more likely it is to have a higher environmental performance. Similarly, the lower the political freedom in a country, the more likely it is to have a lower environmental performance. As a preliminary proposition, therefore, democracy, environmental sustainability, and innovation-driven knowledge economies may have a highly symbiotic and synergistic dynamic and non-linear relationship.
\end{abstract}

Keywords: democracy; environmental sustainability; political freedom; quadruple and quintuple innovation helix frameworks; sustainable development

\section{Introduction}

Democracy and the environment matter for humanity and may well represent "endangered species" [1]. Therefore, the aim of this paper is to explore a possible relationship between democracy and the environment, and more specifically between freedom and environmental sustainability (environmental performance). In the context of this article, no major distinction was drawn between environmental sustainability and environmental performance, as environmental performance is understood in terms of how environmental sustainability is being performed. Perhaps the theoretical work here is already more advanced (see, for example, [2]). The intention is to examine whether empirical patterns can possibly be identified and, if so, how they are structured and which analytical propositions are available to interpret results. The character of this analysis was exploratory in nature; therefore, we did not discuss causality. The method applied is the explicit use of correlations (Pearson). It was regarded as important to apply the exploratory means of correlations so as to promote and apply more advanced statistical means in a later phase 
of research (which are beyond the scope of this article). The methodological model will relate political freedom with environmental performance for essentially all the countries in the world (those with a population of one million or more, or 156 countries) in reference to the year 2016. In methodological terms, the research question can be phrased as follows: What is the correlation between political freedom and environmental performance? Correlation analysis, here, has the advantage, not to engage in analytical determinism, but to emphasize the principal openness of political processes, and also to be sensitive for possible phenomena such as political stress or political pressure, which democracy and democratization may be facing in the world.

To consider possible interactions and inter-dependencies between freedom and ecology does not constitute something completely new. For example, one can refer to the one question that was raised by Pinto ([3] (p.1)), which was presented the following way:

"We'll argue that there are two different ways to analyze the relation between the two concepts: on the one hand, freedom being often referred to be in competition with ecological sustainability and the imposed limits it requires and, on the other hand, the impacts in individual's freedom due to ecological catastrophe if strict limits are not implemented."

However, the novelty of the approach applied herein is such that it related theories on democracy to theories on innovation, and exposed this to exploratory methodological means such as correlation. Innovation is regarded as important for the economy, and higher education also seems to be organically connected with both economic growth and innovation capabilities. In the context of the analysis herein, democracy and the ecology were integrated as essential components for a sufficiently comprehensive understanding of innovation. Therefore, for the theoretical framing of our analysis, we referred to the concept of the Quadruple and Quintuple Innovation Helix Frameworks [4-6], which extends the earlier approach of the Triple Innovation Helix. The Quadruple Innovation Helix (ibid.) emphasizes the importance of democracy, knowledge democracy, and the quality of democracy for knowledge and innovation, and the Quintuple Innovation Helix emphasizes the importance of ecology, the environment, environmental sustainability, and climate, similarly for knowledge production and innovation and innovation systems. Should it be possible to indicate possible empirical patterns and relations between democracy and the environment (freedom and environmental sustainability), then this may also indicate scenarios, opportunities, and also threats concerning the further evolution of innovation systems.

The paper has the following structure: in Section 2, the conceptual building elements of the Quadruple and Quintuple Innovation Helix Frameworks were reviewed, demonstrating how democracy and the ecology are designed to network in favor of innovation. Section 3 focused on the empirical model, i.e., linking and correlating political freedom with environmental performance. The components of the model were documented, and the empirical results of the data processing were summarized. Finally, the conclusion, presented in Section 4, reviewed the outcome of the entire inquiry and discussed possible implications of the manifest relationship between democracy and the environment for knowledge and innovation.

\section{Conceptual Building Elements of the Quadruple and Quintuple Innovation Helix Frameworks: Networking Democracy and Ecology for Innovation}

"The competitiveness and superiority of a knowledge system or the degree of development of a knowledge system are particularly determined by their adaptive capability and capacity to combine and integrate several and different modes of knowledge and innovation through co-opetition (cooperation and competition), co-evolution and co-specialization', also of knowledge stock-and-flow dynamics ... " (see [7,8] (p. 201); also in relation to 'Co-Opetition', see [9]).

One idea suggests that there are some analogies between diversity and heterogeneity in advanced knowledge economies and societies, as well as political diversity and pluralism in a democracy. The latter can also be framed as a knowledge democracy, which 
expresses qualities of the quality of democracy. The term and concept of 'democracy of knowledge [10,11] (p. 55) refers to this relationship.

The relationships between academia, industry, and government are highlighted by the Triple Helix [12,13]. In this sense, the Triple Helix can be regarded as a basic, core model for explaining knowledge production and knowledge application in a knowledge economy. The Quadruple Helix and Quintuple Helix are designed as an innovation system framework to address the complexity and context of knowledge production and application (innovation) more broadly and elegantly. The analytical architecture is becoming expanded. By this, phrasing it metaphorically, the Triple Helix is embedded in the Quadruple Helix, and the Quadruple Helix is embedded in the Quintuple Helix. The Quadruple Helix contributes as the fourth helix in the media-based and culture-based public arts, artistic research, arts-based innovation, democracy and knowledge democracy, and in effect and essence, the civil society, referring to a democratic knowledge society and economy stakeholders such as creators, inventors, innovators, and entrepreneurs: "The Quadruple Helix innovation model can be seen as a model that integrates the dimension of democracy or the context of democracy in order to promote knowledge, knowledge production and innovation" [11] (p. 14) (see also $[8,10,14-27])$. The Quintuple Helix is the fifth helix or dimension in the ecological perspective of the natural environment of society and economy [14] (p. 62) (see also [4-6]), as shown in Figure 1, which illustrates and emphasizes how democracy (knowledge democracy) and the environment (for example, social ecology and the climate) matter for knowledge and innovation.

\section{Quintuple Helix: Social Ecology, Environment (Environments)}

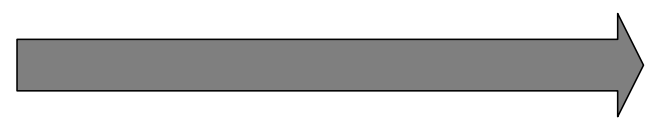

\section{Quadruple Helix: Knowledge Society, Knowledge Democracy}

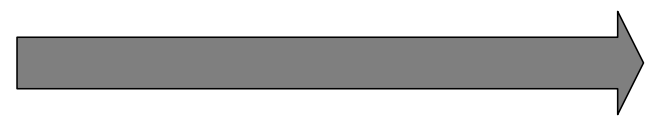

\section{Triple Helix: Knowledge Economy}

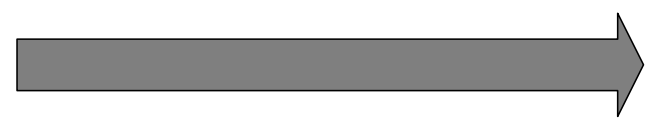

Figure 1. The five-dimensional structure of innovation and innovation systems. Source: Authors' own visualization, see also [8] (p. 207), [12] (p. 112), [14] (p. 62), [4] (p. 4), [28] (p. 65), furthermore, see $[20,23]$.

The Triple Helix is direct in recognizing higher education as important insofar as innovation is concerned. However, the Triple Helix is inclined to emphasize, in reference to knowledge production and innovation, the economy; the Triple Helix is therefore sensitive regarding themes connected to the knowledge economy. The Quadruple Helix introduces new perspectives on society and democracy. The Quadruple Helix emphasizes that sustainable development of and in the economy eventually requires a co-development and co-evolution of the knowledge economy, knowledge society, and knowledge democracy. The Quadruple Helix indicates that a knowledge society and a knowledge democracy are actually necessary for advanced forms of knowledge production (research) and knowledge application (innovation). In addition, the Quadruple Helix encourages the understanding that not only the universities (higher education institutions) of the sciences are decisive, but also that the universities (higher education institutions) of the arts are crucial in contributing to the further advancement of knowledge and innovation systems; this promotes inter-disciplinarity and trans-disciplinarity so as to support a networking between the sciences and arts and therein contribute to create creative knowledge production and inno- 
vation. This encourages next steps in future-oriented knowledge and innovation. Social ecology focuses on interactions between society and nature (society-nature interactions), more precisely between human society and the material world (in this regard, see, for example, [29]). The European Commission clearly identified the socio-ecological transition of the economy and society as one of the greatest needs and challenges ahead [30]. However, this also should be seen and understood as an opportunity for future progress, for the advancement of the knowledge economy, society, and democracy. The Quintuple Helix refers to the socio-ecological transition of the economy, society, and democracy. This underscores the ecologically sensitive design of the Quintuple Innovation Helix Framework.

The Quintuple Innovation Helix Framework bases its conception of knowledge production (research) and knowledge application (innovation) on social ecology. Environmental problems (global warming, for example) clearly represent issues of survival for humanity and for human civilization. However, the Quintuple Helix also identifies environmental problems and ecological problems as possible drivers for the creation of a responsible future knowledge (production) and responsible future innovation, where responsibility constitutes combining the ecological responsibility for the environment with a social responsibility for society and democracy [4]. This motivates learning processes in a knowledge economy, or at least has potential in such directions: "The Quintuple Helix supports here the formation of a win-win situation between ecology, knowledge and innovation, creating synergies between economy, society and democracy" [4] (p. 1).

Therefore: "The Democracy of Knowledge, as a concept and metaphor, highlights and underscores parallel processes between political pluralism in advanced democracy, and knowledge and innovation heterogeneity and diversity in advanced economy and society. Here, we may observe a hybrid overlapping between the knowledge economy, knowledge society and knowledge democracy" [11] (p. 55). Ideas of a knowledge economy extend beyond a republic of science [31], but they also relate to concepts of the democratization of innovation [32,33].

Quality of democracy, as a concept and approach, focuses on framing and defining democracy beyond the minimum standards as they are being set out in the so-called electoral democracy. Quality of democracy refers to more advanced forms of democracy, and indicates what possible pathways of progress and further development and evolution of democracy exist. Crucial and decisive in this respect was the work of Guillermo O'Donnell [34,35]. The work of O'Donnell also relates to the work of Amartya Sen [36,37]. There are also other authors who refer to quality of democracy (see, for example, [38-49]). Altogether, a pluralism of concepts of democracy, and a pluralism of measurement of democracy, already exists (see [42,46,50] (pp. 370-398), and [51-58]). Furthermore, there is also research in inquiring whether there are patterns or trends in the relationship between democracy and development, or between democracy, economic growth, and development [15,59-68]. Guillermo O'Donnell's work, significantly, drew a connection between human development and human rights [34,35], and is interwoven with the work of Amartya Sen [36,37]. When more closely investigating possible linkages or cross-linkages between democracy and development, over the time period of 1950-1990, Przeworski, Alvarez, Cheibub, and Limongi asserted:

"Hence, if the patterns we have observed persist, the world will be better, much better. More people will be living in democracies; they will be wealthier; and they will be enjoying all the benefits that wealth brings, probably including great improvements in public health and medical technology. But not all of us will enjoy this progress. Poverty will still be widespread, dictators will still repress, and wars will still ruin lives" [67] (p. 277).

A detailed literature review regarding the relationships among the aforementioned concepts of democracy, political freedom, and the environment (i.e., democracy and the environment, democracy and political freedom, and political freedom and the environment) is out of the scope of this paper, given the vast number of previous studies. However, it should be noted that the rule of law is an essential part of the quality of democracy, given that democratic rights depend on the degree to which such rights are recognized in practice [34]. On the other hand, this conceptualization is rather difficult mainly because 
the boundaries between democracy and the rule of law are vague; constitutional traditions and geopolitical interests may also complicate this relationship. Similarly, the linkages between freedom and development may be examined in a broader sense. As Amartya Sen notes, freedom should be addressed only in economic and political terms, but it should also consider the freedom to access social services; therefore, freedom is strongly associated with quality of life [36].

Although there are very different and conflicting views in the relevant literature regarding the relationship between democracy and the environment, several studies propose a number of arguments that strongly support a positive relationship between democracy and environmental protection [69]:

- Given that democracies respect individual rights, environmentalists may promote and influence decisions about environmental legislation.

- Democratic governments are inherently more responsive to their citizenry, assuring a minimum level of accountability.

- Free flowing information in democracies allows for a form of political learning, including scientific arguments regarding environmental problems.

- Democratic governments are more likely to cooperate with each other insofar as international environmental agencies and treaties are concerned.

- Given that democracies are usually based on free-market economies, businesses can be subject to both environmental incentives and sanctions.

Hans-Joachim Lauth [70] suggested a three-dimensional modelling of democracy, referring to the dimensions of freedom, equality, and control (see also [71-74]). In the words of Lauth, freedom (political freedom) represents a basic foundation for democracy, implying that without the accomplishment of a sufficient degree of (political) freedom, a democracy is not possible. Therefore, democracy requires (among other characteristics) freedom. For earlier work regarding the importance of freedom for democracy, see, for example, the collection of essays in Bohmann and Rehg [75]. The three-dimensional model (of Lauth) was extended by Campbell (see [76] (p. 296), [77] (p. 33), and [78]) to a five dimensional model by adding the dimensions of sustainable development and of self-organization (political self-organization) (see Figure 2). Figure 2 emphasizes that a comprehensive approach to democratic measurement and the measurement of the quality of democracy requires taking a dimension such as sustainable development into account, which also includes environmental sustainability. In this sense it could be speculated whether there are structural synergies between the five dimensions of the Quintuple Innovation Helix Framework and a broader quality-of-democracy understanding (compare Figures 1 and 2).

"For the Quadruple and Quintuple Innovation Helix Frameworks, democracy and ecology (environmental protection) are constituting categories, without these a Quadruple and Quintuple Helix innovation system not possible is. To elevate here to next levels, implications could be that climate (as a component and crucial category of ecology), so to say climate itself, is being integrated into understandings of democracy and quality of democracy. 'Democracy of Climate' (creating a 'climate for democracy', desirably a 'positive climate' for democracy), in co-creation with a 'democracy of knowledge' (emphasizing a co-evolution of political pluralism and a diversity of knowledge modes in innovation), are referring to new designs and performances of innovation and innovation systems, being furthermore ex-pressed in the principles, building blocks and design of Quadruple and Quintuple Innovation Helix Frameworks. Democracy enables and encourages innovation, and the ecology and cli-mate can act as drivers for further innovation" [1]. 
Freedom

Equality

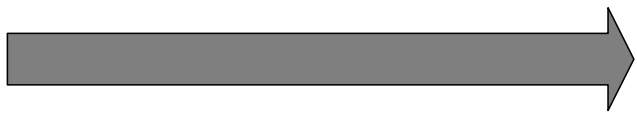

Control

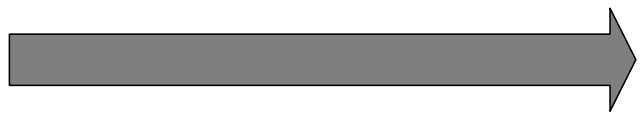

\section{Sustainable Development}

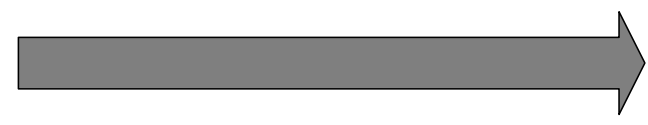

\section{Self-Organization (Political Self-Organization)}

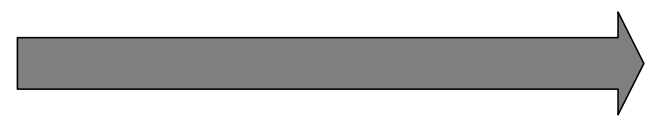

Figure 2. The five-dimensional structure of democracy and quality of democracy. Source: Author's own visualization based on [51] (p. 32), [76] (p. 296), [77] (p. 33), [79] and for the dimension of 'control' based on [70] (pp. 32-101).

Examples of academic research regarding the linkages between "Democracy and Climate Change" and "Climate Change and the Future of Democracy" can be found in $[80,81]$ Therefore, they are also examples of topics in the variation of democracy and the climate. Furthermore, a more radical example would refer to a democracy of climate, as was being suggested by Carayannis and Campbell [1]. Ecology, ecological challenges (e.g., global warming), and environmental protection matter in terms of the survival of humanity, but also in terms of the further development and advancement of human civilization, not only on earth, but also beyond earth [10]. One radical implication of this is that the governance of climate should be regarded as a quality criterion for democracy, and more specifically the aspect of sustainable development $[1,10,77,82,83]$. In this sense, democracy, innovation, and ecology (climate) are hypothesized to be interconnected and to work together and, by this, create, enable and perform sustainable development [77].

\section{Empirical Analysis: Linking Political Freedom with Environmental Performance}

This section presents a preliminary empirical analysis of potential linkages between the environment and political freedom. According to Carayannis [1], "the environment should be regarded as an active partner of innovation, not a resource to be exploited". In this sense, all of the three pillars of sustainability should be considered, i.e., environmental, social, and economic sustainability. The presented empirical analysis focused on environmental sustainability in order to emphasize the environmental and ecological problems considered in the Quintuple Innovation Helix Framework.

Political freedom refers to the dimension of political freedom, as mentioned by Campbell [77] (Table A.2.1, pp. 356-365). The political freedom score is based on equal weighting aggregation of the following indicators:

- Political rights;

- Civil liberties;

- $\quad$ Freedom of the press. 
Data for the previous three indicators was provided by Freedom House [56,84,85], while the aggregated political freedom score was rescaled to $0-100$, where 0 represented the lowest observed freedom level and 100 the highest observed freedom level. Freedom House was used as a source for data on political freedom because they represent an established and internationally recognized institution within this area, and their data are publically accessible. Furthermore, a data review and clearance was processed for the political freedom data that we used, in accordance with [77]. As Campbell ([77], (pp. 265-277)) demonstrated, the political freedom data provided by Freedom House clearly pass a test of validity.

Figures 3 and 4 present the evolution of political freedom in 2002-2016 in different country groups based on World Bank's geographic areas and income levels. These figures present the average of the countries belonging to each group, and we may observe that, despite some variations, the political freedom score is somewhat stable, without major improvements in the examined period. Low income and sub-Saharan African countries appeared to have the lowest political freedom, while high income counties or countries in North America, Europe, and Central Asia seemed to have the highest freedom scores. Generally, as shown in Figure 4, income was directly related with political freedom.

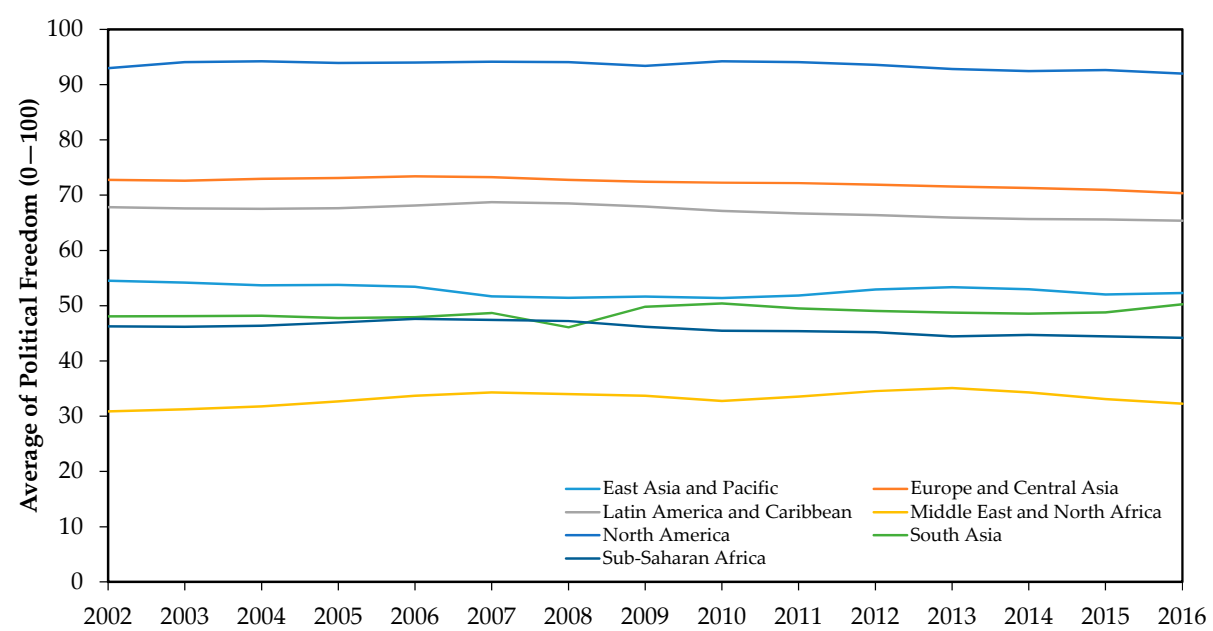

Figure 3. Political freedom scores in 2002-2016 by geographical area. Source: author's own visualization based on [77].

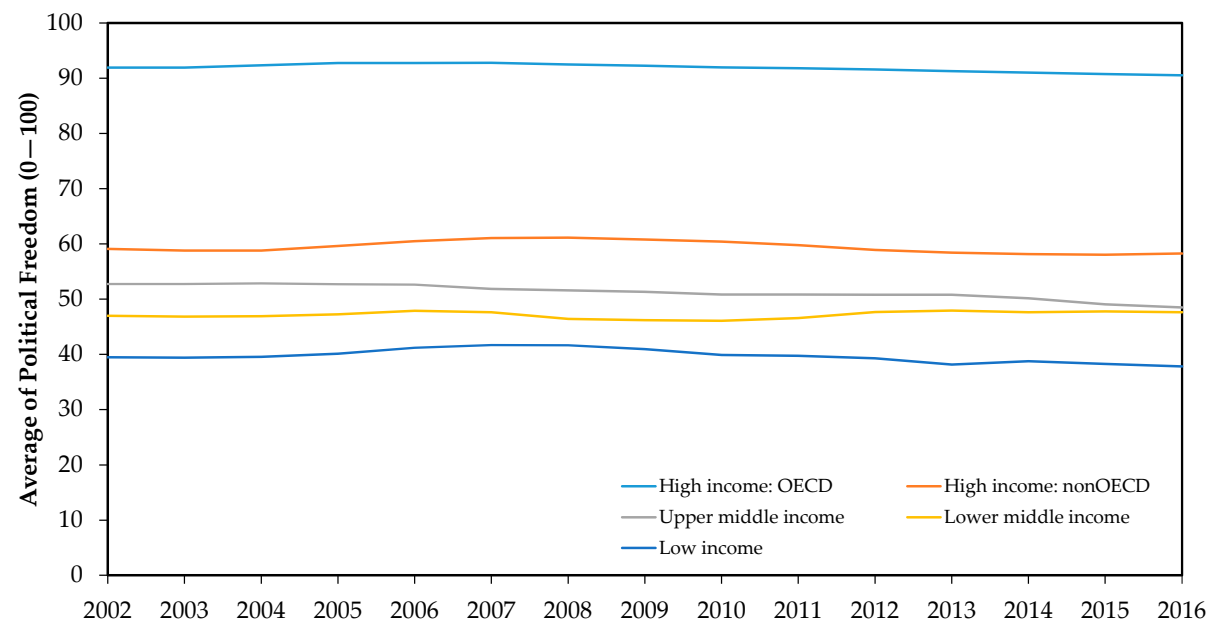

Figure 4. Political freedom scores in 2002-2016 by income group. Source: author's own visualization based on [77].

For the environment, we use the Environmental Performance Index (EPI) published by the Center for Environmental Law and Policy of Yale University, in collaboration 
with Columbia University's Center for International Earth Science Information Network (CIESIN) and the World Economic Forum (WEF) (see also [86]). The 2016 version of EPI is a barometer of environmental performance that measures 20 indicators across nine major policy categories: health impacts, air quality, water and sanitation, water resources, agriculture, forests, fisheries, biodiversity and habitat, and climate and energy [87]. Figure 5 presents the general EPI framework.

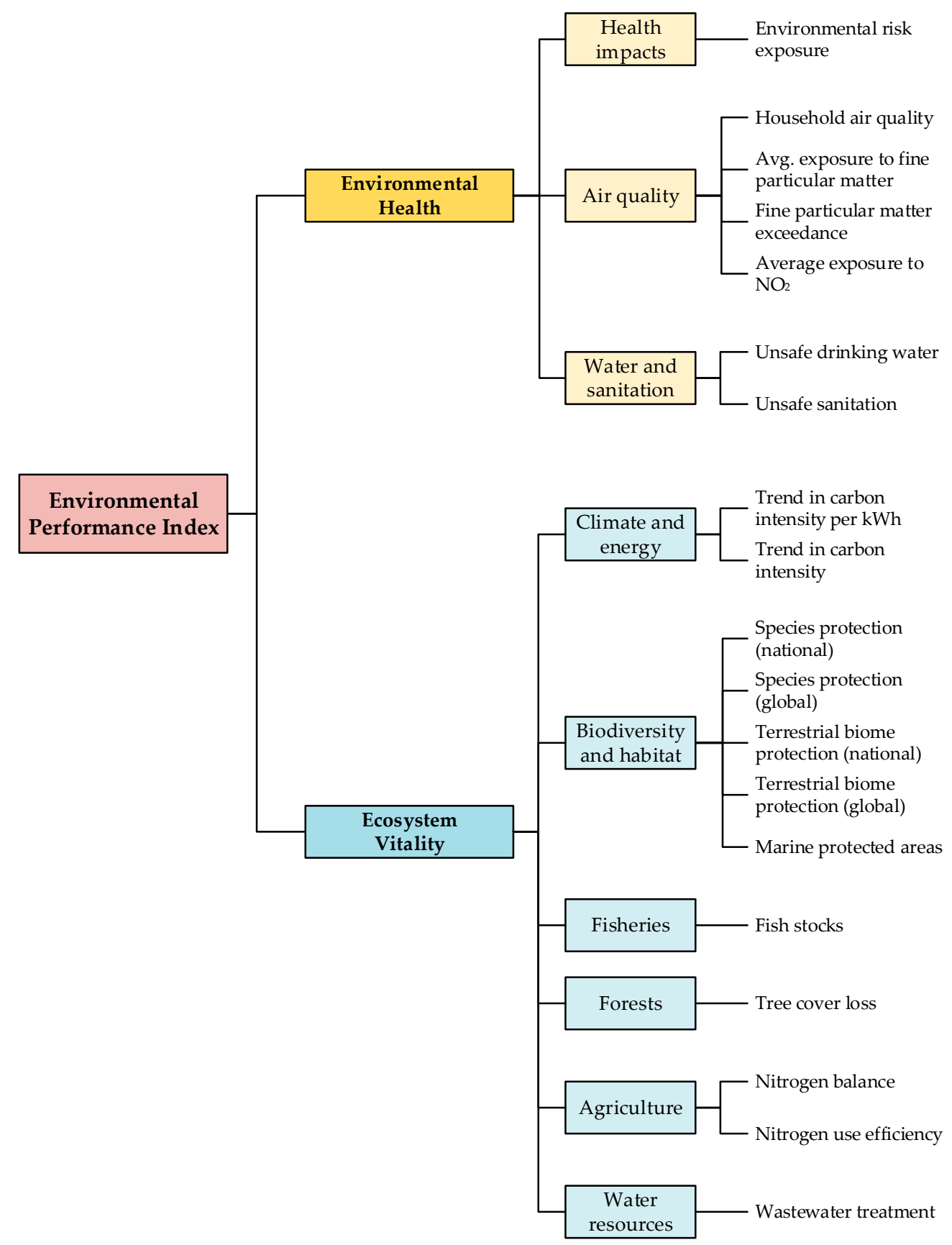

Figure 5. General EPI framework. Source: author's own visualization based on [87].

Using standard normalization approaches (e.g., based on population, land area, and gross domestic product) and statistical transformations, EPI transforms raw data into comparable performance indicators. EPI indicators are based on a proximity-to-target methodology, which assesses how close each country is to a specific policy target as defined by international or national policy goals or established scientific thresholds. 
The final EPI score is based on a simple weighted scheme; the two major objectives of environmental health and ecosystem vitality are weighted equally, while individual indicators are weighted based on their relevance for assessing a specific policy issue, as well as the quality of the underlying data (see also [87]).

In order to examine the relation between political freedom and environment, we developed a database for the aforementioned scores for a total of 156 countries. In order to achieve a global perspective, we considered all countries in the world with a population of more than a million people. Then, we calculated the Pearson correlation coefficient between the Political freedom score and the Environmental Performance Index. This showed that there is a significant positive correlation between freedom and environmental performance, with $R=0.5577$, with $p<0.001$ (two-tailed). This result indicates the linkages between democracy and environment, since higher the political freedom levels correlate to higher environmental performance of a country. Figure 6 presents a scatterplot between the political freedom and the EPI scores in 2016, demonstrating this relation.

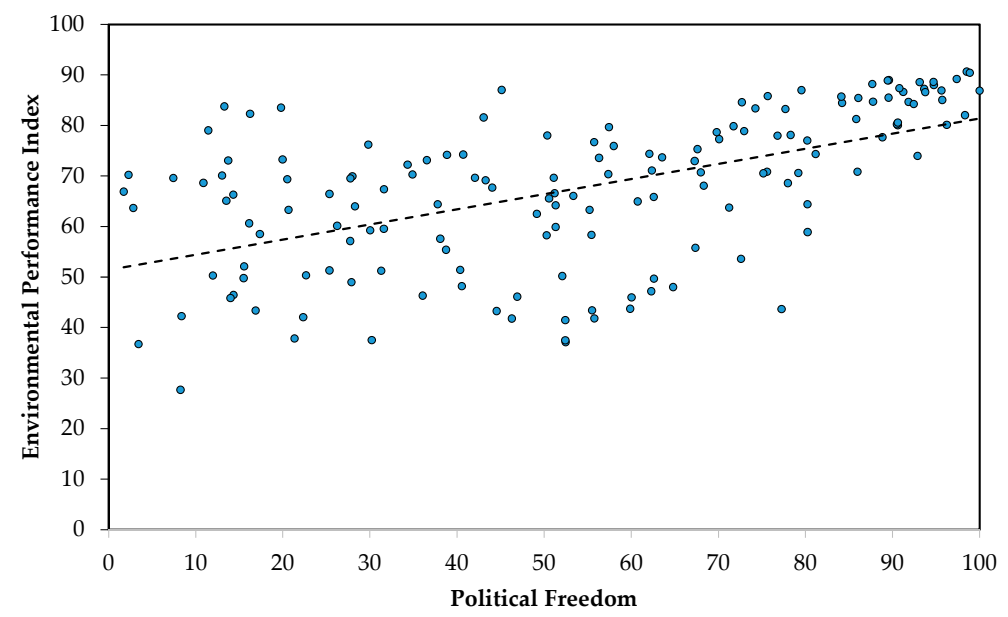

Figure 6. Political freedom vs. environmental sustainability (2016). Source: author's own visualization based on $[77,88]$.

We may also further analyze the previous findings by examining democracy and environment in different country groups. For example, Table 1 shows the average political freedom score and the Environmental Performance Index in different regions. As shown, the average political freedom level is higher in North America, Europe and Central Asia, and Latin America and the Caribbean, and lower in the Middle East and North Africa and sub-Saharan Africa.

Table 1. Average political freedom and environmental sustainability scores by geographical area. Source: Author's own calculations based on based on $[77,88]$.

\begin{tabular}{ccc}
\hline Geographical Area & $\begin{array}{c}\text { Political Freedom } \\
\text { Score } \mathbf{1}^{1}\end{array}$ & $\begin{array}{c}\text { Environmental Performance } \\
\text { Index }^{\mathbf{1}}\end{array}$ \\
\hline East Asia and Pacific & 50.778 & 67.005 \\
Europe and Central Asia & 69.391 & 81.639 \\
Latin America and Caribbean & 64.259 & 72.360 \\
Middle East and North Africa & 30.113 & 67.807 \\
North America & 91.724 & 84.890 \\
South Asia & 48.685 & 50.005 \\
Sub-Saharan Africa & 42.414 & 52.213 \\
\hline
\end{tabular}

${ }^{1}$ Data in $0-100$.

Figure 7 presents a scatterplot showing the relation between the average Political freedom score and the Environmental Performance Index in the previous regional country 
groups. Giving that these average values may overcome the problem of outliers and possible heterogeneity, the aforementioned positive correlation between freedom and environmental performance appears stronger, with $R=0.7290$, with $p<0.001$ (two-tailed).

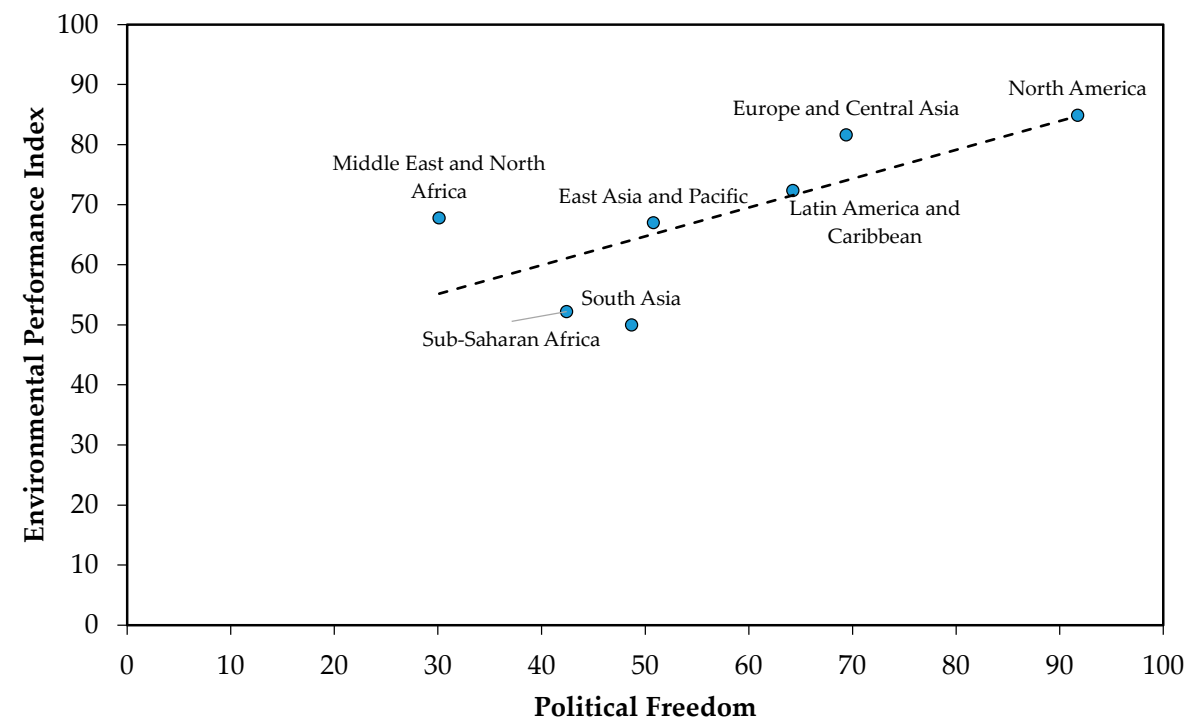

Figure 7. Political freedom vs. environmental sustainability by geographical area (2016). Source: Author's own visualization based on based on $[77,88]$.

Finally, Table 2 shows the average political freedom score and the Environmental Performance Index in the World Bank's different income groups. As shown, the average political freedom level was higher in high income countries; this may also suggest that income is important in the democracy-environment relationship.

Table 2. Average political freedom and environmental sustainability scores by income group. Source: author's own calculations based on $[77,88]$.

\begin{tabular}{ccc}
\hline Geographical Area & $\begin{array}{c}\text { Political Freedom } \\
\text { Score } \mathbf{~}^{\text {B }}\end{array}$ & $\begin{array}{c}\text { Environmental Performance } \\
\text { Index }^{\mathbf{1}}\end{array}$ \\
\hline High income: OECD & 90.215 & 85.112 \\
High income: non OECD & 56.938 & 74.889 \\
Upper middle income & 46.864 & 73.209 \\
Lower middle income & 45.957 & 60.759 \\
Low income & 35.864 & 47.613 \\
\hline
\end{tabular}

${ }^{1}$ Data in $0-100$

\section{Conclusions}

The main objective of this paper was to present a discussion and a preliminary empirical analysis of the inter-relations between climate, development, and democracy. The presented analysis was purely explorative in nature. In methodological terms, our analysis was based on the following research question: What is the correlation between political freedom and environmental performance? Therefore, the core empirical model, for which we opted, employed a correlation analysis plotting political freedom and environmental performance for essentially all the countries in the world (i.e., countries with a population of more than a million, totaling 156 countries). The empirical outcome was a positive Pearson correlation of about 0.56 (or 0.73 if we examine regional country groups) and, perhaps even more significantly, this correlation was significant at the 0.001 level (two-tailed).

What this correlation tells us is that, simply: The higher the political freedom in a country, the more likely it is to have a higher environmental performance. Similarly, the lower the political freedom in a country, the more likely it is to have a lower environmental 
performance. Of course, since Pearson's correlation coefficient is not able to identify cause and effect, the previous findings need further analysis, validation, and justification in order to understand the aforementioned interrelations.

However, it should be stressed that correlation is not causation. We should consider that it is almost impossible to suggest that results show causal determinism, which might imply that lower environmental performances are automatically interlinked with authoritarianism or lead to authoritarianism. Moreover, the presented results may indicate a spurious correlation, despite the existence of studies that justify the interrelations between democracy and the environment. Therefore, in order to confirm that the aforementioned correlations are sound, additional variables should be considered in order to model an integrated dynamic environment-democracy system (see also [89]). Consequently, the presented preliminary empirical results mainly emphasize the necessity to further research the democracy-environment nexus. Simultaneously, it should be emphasized that such early-stage correlative work can help in the preparation of later work with more advanced statistical means.

In this presented context, the paper also highlighted the Quadruple and Quintuple Innovation Helix Frameworks that can serve as architects for a better future and emphasize that, over the medium to long term, true and transparent democracy constitutes a sine qua non for smart, sustainable, and inclusive growth. Regarding the conceptual theory work, what was being attempted herein was to cross-associate theories about the quality of democracy with theories about innovation. For example, the five dimensions of democracy (Figure 2) encourage comparative analytics along the lines of the five helices of the Quintuple Innovation Helix Framework (Figure 1).

As noted by Carayannis [1], "we need to change the way we envision both business and society. The old ways have worn themselves out. We are having both a crisis of democracy and a climate crisis. They are both the result of a limited way of thinking". Similarly, Campbell [77] notes that

“... perhaps the economic successes of non-democracies or autocracies (authoritarian and semi-authoritarian regimes) are being overestimated anyway, because autocracies are also benefitting from the knowledge production and innovation systems of democracies and semi-democracies, so in that sense autocracy is depending on democracy and the knowledge and innovation of democracy in a global system."

On the other hand, the findings may indicate certain risk profiles. In this sense, we can employ the metaphor that poor environmental performance, accompanied by other environmental problems and challenges, is putting democracy and democratization under stress. To be more precise, perhaps it should be said that it is particularly the process of further democratization that is under pressure. Established democracies are perhaps in a better (or easier) position to cope with environmental challenges. This may associate with the so-called "Hypothesis 14" in the conclusion of the work of Campbell ([77], (p. 329)), which asserted: "There may be more of a comparative win-win situation in the OECD countries, but a comparative trade-off situation in non-OECD countries". However, transitions from autocracy to democracy may become more difficult, so the successful transitions to democracy will require additional efforts.

Global warming, including other negative environmental developments, has several implications and ramifications. It is related to the survival of human civilization. However, there is apparently also a direct nexus of global warming to democracy. The tensions that global warming is creating also pose a direct threat to democracy, as poor (or decreasing) environmental performance may constrain freedom by favoring authoritarian tendencies. Therefore, the prevalence of democracy in the world will also require the implementation of solutions and problem-solving regarding important ecological themes. The prospering of democracy is also tied to the environmental challenge of sustainability.

Future research efforts should examine additional data that can better explain factors related to climate change and global warming, such as rising temperatures, extreme weather events, rising sea levels, and etc. in the context of socio-political, socio-economic, and socio- 
technical dynamics. Furthermore, mitigation and adaptation policies to climate change may also explain the relation between democracy and environment. Climate change is a global issue that requires global cooperation and long-term commitments; the quality of democracy, therefore, is a key factor. As noted by several scholars, democracies are characterized by the free flow of information regarding problems and solutions, increased administrative capacities, lower levels of corruption, improved scientific and technical capacity, and dynamic, innovative economies [90,91]. In this context, under a Quadruple and Quintuple Helix approach (Quadruple and Quintuple Innovation Helix Frameworks), it will be interesting to examine the role of civil society and innovation in a more holistic environment-democracy-innovation nexus.

The concept of the Quintuple Innovation Helix Framework attempts to address ecological challenges, serving as a driver for further innovation and knowledge production. The concept of the Quadruple Innovation Helix Framework asserts that an advanced knowledge democracy is actually necessary to advance knowledge and innovation. To some extent, democracy is 'doomed' to succeed in approaching the ecological issues and, again, it may only be democracy, finally creating and generating the knowledge and innovation, which is necessary to solve the ecological challenges for a new future. Educational organizations and higher education institutions (for example universities) can be expected to play a crucial role. Democracy, environmentalism, and the innovation-driven knowledge economy may be co-evolving.

Author Contributions: Conceptualization, E.G.C.; methodology, E.G.C., D.F.J.C.; formal analysis, E.G.C., D.F.J.C., E.G.; writing E.G.C., D.F.J.C., E.G.; review and editing, E.G.C., D.F.J.C., E.G. All authors approved the final version. All authors have read and agreed to the published version of the manuscript.

Funding: This research received no external funding.

Data Availability Statement: The data that support the findings of this study are available in $[70,83]$.

Conflicts of Interest: The authors declare no conflict of interest.

\section{References}

1. Carayannis, E.G. Democracy and the Environment Are Endangered Species, Interview with Dr. Prof. Elias Carayannis by Charlotte Koldbye. RiConfigure. Available online: http:/ / riconfigure.eu/wp-content/uploads/2020/01/Interview-with-EliasCarayannis_2020_Final.pdf (accessed on 28 February 2021).

2. Carayannis, E.G.; Campbell, D.F.J. Democracy of climate and climate for democracy: The evolution of Quadruple and Quintuple Helix innovation systems. J. Knowl. Econ. 2021. [CrossRef]

3. Pinto, J. Freedom and ecological limits. Crit. Rev. Int. Soc. Political Philos. 2018, 1-17. [CrossRef]

4. Carayannis, E.G.; Barth, T.D.; Campbell, D.F.J. The Quintuple Helix Innovation Model: Global warming as a challenge and driver for innovation. J. Innov. Entrep. 2012, 1, 1-12. [CrossRef]

5. Carayannis, E.G.; Grigoroudis, E.; Campbell, D.F.J.; Meissner, D.; Stamati, D. The ecosystem as helix: An exploratory theorybuilding study of regional co-opetitive entrepreneurial ecosystems as Quadruple/Quintuple Helix Innovation models. $R D$ Manag. 2018, 48, 148-162.

6. Carayannis, E.G.; Grigoroudis, E.; Campbell, D.F.J; Meissner, D.; Stamati, D. 'Mode 3' universities and academic firms: Thinking beyond the box trans-disciplinarity and nonlinear innovation dynamics within coopetitive entrepreneurial ecosystems. Int. J. Technol. Manag. 2018, 77, 145-185. [CrossRef]

7. Carayannis, E.G. The Strategic Management of Technological Learning: Learning to Learn and Learning to Learn-How-To-Learn as Drivers of Strategic Choice and Firm Performance in Global, Technology-Driven-Markets; CRC Press: Boca Raton, FL, USA, 2001.

8. Carayannis, E.G.; Campbell, D.F.J. “Mode 3" and "Quadruple Helix": Toward a 21st century fractal innovation ecosystem. Int. J. Technol. Manag. 2009, 46, 201-234. [CrossRef]

9. Brandenburger, A.M.; Nalebuff, B.J. Co-Opetition, 1st ed.; Currency Doubleday: New York, NY, USA, 1997.

10. Carayannis, E.G.; Campbell, D.F.J. Smart Quintuple Helix Innovation Systems: How Social Ecology and Environmental Protection Are Driving Innovation, Sustainable Development and Economic Growth; SpringerBriefs in Business; Springer: New York, NY, USA, 2019.

11. Carayannis, E.G.; Campbell, D.F.J. Mode 3 Knowledge Production in Quadruple Helix Innovation Systems: 21st-Century Democracy, Innovation, and Entrepreneurship for Development; Springer Briefs in Business; Springer: New York, NY, USA, 2012.

12. Etzkowitz, H.; Leydesdorff, L. The dynamics of innovation: From national systems and "Mode 2" to a Triple Helix of universityindustry-government relations. Res. Policy 2000, 29, 109-123. [CrossRef] 
13. Cai, Y.; Lattu, A. Synergy Building between Triple Helix and Quadruple Helix; Faculty of Management and Business, University of Tampere: Tampere, Finland, 2020.

14. Carayannis, E.G.; Campbell, D.F.J. Triple Helix, Quadruple Helix and Quintuple Helix and how do knowledge, innovation and the environment relate to each other? A proposed framework for a trans-disciplinary analysis of sustainable development and social ecology. Int. J. Soc. Ecol. Sust. Dev. 2010, 1, 41-69. [CrossRef]

15. Carayannis, E.G.; Campbell, D.F.J. Developed democracies versus emerging autocracies: Arts, democracy, and innovation in Quadruple Helix Innovation Systems. J. Innov. Entrep. 2014, 3, 1-23. [CrossRef]

16. Carayannis, E.G.; Pirzadeh, A. The Knowledge of Culture and the Culture of Knowledge. Implications for Theory, Policy and Practice; Palgrave Macmillan: London, UK, 2014.

17. Carayannis, E.G.; Christodoulou, K.; Christodoulou, P.; Chatzichristofis, S.A.; Zinonos, Z. Known unknowns in an era of technological and viral disruptions: Implications for theory, policy, and practice. J. Knowl. Econ. 2021. [CrossRef]

18. Carayannis, E.G.; Dezi, L.; Gregori, G.; Calo, E. Smart environments and techno-centric and human-centric innovations for Industry and Society 5.0: A Quintuple Helix Innovation System view towards smart, sustainable, and inclusive solutions. J. Knowl. Econ. 2021. [CrossRef]

19. Campbell, D.F.J.; Carayannis, E.G. The academic firm: A new design and redesign proposition for entrepreneurship in innovationdriven knowledge economy. J. Innov. Entrep. 2016, 5, 1-10. [CrossRef]

20. Campbell, D.F.J.; Carayannis, E.G.; Bast, G. Conclusion: The future of the future of education and labor. In The Future of Education and Labor; Bast, G., Carayannis, E.G., Campbell, D.F.J., Eds.; Springer: New York, NY, USA, 2019; pp. $245-253$.

21. Bast, G.; Carayannis, E.G.; Campbell, D.F.J. (Eds.) Arts, Research, Innovation and Society; Springer: New York, NY, USA, 2015.

22. Bast, G.; Carayannis, E.G.; Campbell, D.F.J. (Eds.) The Future of Education and Labor; Springer: New York, NY, USA, 2019.

23. Danilda, I.; Lindberg, M.; Torstensson, B.M. Women Resource Centres: A Quattro Helix Innovation System on the European agenda. In Proceedings of the Triple Helix VII: 7th Biennial International Conference on University, Industry \& Government Linkages, Glasgow, UK, 17-19 June 2009.

24. De Oliveira Monteiro, S.P.; Carayannis, E.G. (Eds.) The Quadruple Innovation Helix Nexus. A Smart Growth Model, Quantitative Empirical Validation and Operationalization for OECD Countries; Palgrave Macmillan: New York, NY, USA, 2017.

25. Eigelsreiter, B. Consumerization of IT, cyber-democracy and cyber-crime: The inherent challenges and opportunities of different ends of a continuum. In Handbook of Cyber-Development, Cyber-Democracy, and Cyber-Defense; Carayannis, E.G., Campbell, D.F.J., Efthymiopoulos, M.P., Eds.; Springer: New York, NY, USA, 2018; pp. 565-594.

26. Hemlin, S.; Allwood, C.M.; Martin, B.R. Creative Knowledge Environments. The Influences on Creativity in Research and Innovation; Edward Elgar Publishing: Cheltenham, UK, 2004.

27. Mitterlehner, B. Cyber-Democracy and cybercrime: Two sides of the same coin. In Cyber-Development, Cyber-Democracy and CyberDefense: Challenges, Opportunities and Implications for Theory, Policy and Practice; Carayannis, E.G., Campbell, D.F.J., Efthymiopoulos, M.P., Eds.; Springer: New York, NY, USA, 2014; pp. 207-230.

28. Galan, M.; Campbell, D.F.J.; Carayannis, E.G. The role of Information and Communication Technology (ICT) in the governance of energy access: Exploring application of Quadruple and Quintuple Helix Innovation theory in technology transfer. In Handbook of Cyber-Development, Cyber-Democracy, and Cyber-Defense; Carayannis, E.G., Campbell, D.F.J., Efthymiopoulos, M.P., Eds.; Springer: New York, NY, USA, 2018; pp. 59-85.

29. Fischer-Kowalski, M.; Haberl, H. (Eds.) Socioecological Transitions and Global Change: Trajectories of Social Metabolism and Land Use; Edward Elgar: Cheltenham, UK, 2007.

30. European Commission. The World in 2025: Rising Asia and Socio-Ecological Transition; European Commission: Brussels, Belgium, 2009.

31. Polanyi, M. The republic of science: Its political and economic theory. Minerva 1962, 1, 54-74. [CrossRef]

32. Von Hippel, E. The Sources of Innovation; Oxford University Press: Oxford, UK, 1995.

33. Von Hippel, E. Democratizing Innovation; The MIT Press: Cambridge, MA, USA, 2005.

34. O'Donnell, G. Why the rule of law matters. J. Democr. 2004, 15, 32-46. [CrossRef]

35. O'Donnell, G. Human development, human rights, and democracy. In The Quality of Democracy: Theory and Applications; O'Donnell, G., Cullell., J.V., Iazzetta, O.M., Eds.; University of Notre Dame Press: Notre Dame, IN, USA, 2004; pp. 9-92.

36. Sen, A. Development as Freedom; Anchor Book: New York, NY, USA, 1999.

37. Sen, A. Human rights and capabilities. J. Hum. Dev. 2005, 6, 151-166. [CrossRef]

38. Beetham, D. Key principles and indices for a democratic audit. In Defining and Measuring Democracy; Beetham, D., Ed.; Sage: London, UK, 1994; pp. 25-43.

39. Beetham, D. (Ed.) Defining and Measuring Democracy; Sage: London, UK, 1994.

40. Beetham, D. Freedom as the foundation. J. Democr. 2004, 15, 61-75. [CrossRef]

41. Bühlmann, M.; Merkel, W.; Müller, L.; Weßels, B. The democracy barometer: A new instrument to measure the quality of democracy and its potential for comparative research. Eur. Political Sci. 2011, 11, 519-536. [CrossRef]

42. Coppedgea, M.; Gerring, J.; Altman, D.; Bernhard, M.; Fish, S.; Hicken, A.; Kroenig, M.; Lindberg, S.I.; McMann, K.; Paxton, P.; et al. Conceptualizing and measuring democracy: A new approach. Perspect. Polit. 2011, 9, 247-267. [CrossRef] 
43. Cullel, J.V. Democracy and the quality of democracy: Empirical findings and methodological and theoretical issues drawn from the citizen audit of the quality of democracy in Costa Rica. In The Quality of Democracy: Theory and Applications; O'Donnell, G., Cullell, J.V., Iazzetta, O.M., Eds.; University of Notre Dame Press: Notre Dame, IN, USA, 2004; pp. $93-162$.

44. Diamond, L.; Morlino, L. The quality of democracy: An overview. J. Democr. 2004, 15, 20-31. [CrossRef]

45. Diamond, L.; Morlino, L. Assessing the Quality of Democracy; The Johns Hopkins University Press: Baltimore, MA, USA, 2005.

46. Geissel, B.; Kneuer, M.; Lauth, H.J. Measuring the quality of democracy: Introduction. Int. Political Sci. Rev. 2016, 37, 571-579. [CrossRef]

47. Helms, L. Die Institutionalisierung der Liberalen Demokratie: Deutschland im Internationalen Vergleich; Campus Verlag: Frankfurt, Germany, 2007.

48. Munck, G.L. What is democracy? A reconceptualization of the quality of democracy. Democratization 2016, 23, 1-26. [CrossRef]

49. Munck, G.L.; Verkuilen, J. Conceptualizing and measuring democracy: Evaluating alternative indices. Comp. Political Stud. 2002, 35, 5-34. [CrossRef]

50. Schmidt, M.G. Demokratietheorien: Eine Einführung; VS Verlag für Sozialwissenschaften: Wiesbaden, Germany, 2010.

51. Campbell, D.F.J. The Basic Concept for the Democracy Ranking of the Quality of Democracy; Democracy Ranking: Vienna, Austria, 2008.

52. Campbell, D.F.J.; Barth, T.D. Wie können Demokratie und Demokratiequalität gemessen werden? Modelle, Demokratie-Indices und Länderbeispiele im globalen Vergleich. SWS-Rundschau 2009, 49, 208-233.

53. Campbell, D.F.J.; Carayannis, E.G.; Barth, T.D.; Campbell, G.S. Measuring democracy and the quality of democracy in a worldwide approach: Models and indices of democracy and the new findings of the "Democracy Ranking". Int. J. Soc. Ecol. Sust. Dev. 2013, 4, 1-16. [CrossRef]

54. De Roeck, M.; Van Rossem, R. Fifty Shades of Grey? Conceptualizing and Measuring Political Regimes Using Theories of Democracy; 1972-2010, Working Paper 2015.05; University of Antwerp: Antwerpen, Belgium, 2015.

55. Downs, A. An Economic Theory of Democracy; Harper: New York, NY, USA, 1957.

56. Freedom House Freedom in the World: Aggregate Scores of Political Rights and Civil Liberties 2003-2013; Freedom House: Washington, DC, USA, 2013; Available online: http://www.freedomhouse.org/sites/default/files/AggregateScores_FIW2003-2013\%20\%28 final\%29.xls (accessed on 28 February 2021).

57. Inkeles, A. (Ed.) On Measuring Democracy: Its Consequences and Concomitants; Transaction Publishers: New Brunswick, NJ, USA, 1993.

58. Prainsack, B. Vom Wert des Menschen: Warum wir ein Bedingungsloses Grundeinkommen Brauchen; Brandstätter Verlag: Vienna, Austria, 2020.

59. Brand, U.; Brunnengräber, A.; Schrader, L. Global Governance: Alternative zur Neoliberalen Globalisierung; Westfälisches Dampfboot: Münster, Germany, 2000.

60. Brand, U.; Wissen, M. Imperiale Lebensweise: Zur Ausbeutung von Mensch und Natur in Zeiten des Globalen Kapitalismus; Oekom Verlag: Munich, Germany, 2017.

61. Gerring, J.; Bond, P.; Barndt, W.T.; Moreno, C. Democracy and economic growth: A historical perspective. World Politics 2005, 57, 323-364. [CrossRef]

62. Hadenius, A.; Teorell, J. Cultural and economic prerequisites of democracy: Reassessing recent evidence. Stud. Comp. Int. Dev. 2005, 39, 87-106. [CrossRef]

63. Kesselman, M. Order or movement? The literature of political development as ideology. World Politics 1973, 26, 139-154. [CrossRef]

64. Knutsen, C.H. Democracy and economic growth: A survey of arguments and results. Int. Area Stud. Rev. 2012, 15, 393-415. [CrossRef]

65. Merkel, W. Das Ende der Euphorie: Kehren die Diktaturen zurück? Theoretische und empirische Befunde. WZB-Mitteilungen 2010, 127, 36-39.

66. Morlino, L.; Quaranta, M. What is the impact of the economic crisis on democracy? Evidence from Europa. Int. Political Sci. Rev. 2016, 37, 618-633. [CrossRef]

67. Przeworski, A.; Alvarez, M.E.; Cheibub, J.A.; Limongi, F. Democracy and Development: Political Institutions and Well-Being in the World 1950-1990; Cambridge University Press: Cambridge, UK, 2003.

68. Rothstein, B.; Uslaner, E.M. All for all: Equality, corruption, and social trust. World Politics 2005, 58, 41-72. [CrossRef]

69. Midlarsky, M.I. Democracy and the environment: An empirical assessment. J. Peace Res. 1998, 35, 341-361. [CrossRef]

70. Lauth, H.J. Demokratie und Demokratiemessung. Eine Konzeptionelle Grundlegung für den Interkulturellen Vergleich; VS Verlag für Sozialwissenschaften: Wiesbaden, Germany, 2004.

71. Lauth, H.J. Möglichkeiten und Grenzen der Demokratiemessung. Z. Staats Eur. 2010, 8, 498-529. [CrossRef]

72. Lauth, H.J. Qualitative Ansätze der Demokratiemessung. Z. Staats Eur. 2011, 9, 49-77. [CrossRef]

73. Lauth, H.J. The Internal relationships of the dimensions of democracy: The relevance of trade-offs for measuring the quality of democracy. Int. Political Sci. Rev. 2016, 37, 606-617. [CrossRef]

74. Lauth, H.J.; Schlenkrich, O. Making trade-offs visible: Theoretical and methodological considerations about the relationship between dimensions and institutions of democracy and empirical findings. Politics Gov. 2018, 6, 78-91. [CrossRef]

75. Bohman, J.; Rehg, W. (Eds.) Deliberative Democracy. Essays on Reason and Politics; MIT Press: Cambridge, MA, USA, 1997. 
76. Campbell, D.F.J. Die österreichische Demokratiequalität in Perspektive. In Die Österreichische Demokratie im Vergleich; Helms, L., Wineroither, D.M., Eds.; Nomos: Baden-Baden, Germany, 2012; pp. 293-315.

77. Campbell, D.F.J. Global Quality of Democracy as Innovation Enabler. Measuring Democracy for Success; Palgrave Macmillan: New York, NY, USA, 2019.

78. Campbell, D.F.J.; Carayannis, E.G.; Rehman, S.S. Quadruple helix structures of quality of democracy in innovation systems: The USA, OECD countries, and EU member countries in global comparison. J. Knowl. Econ. 2015, 6, 467-493. [CrossRef]

79. Campbell, D.F.J.; Carayannis, E.G. Quality of democracy and innovation. In Encyclopedia of Creativity, Invention, Innovation and Entrepreneurship; Carayannis, E.G., Ed.; Springer: New York, NY, USA, 2013; pp. 1527-1534.

80. Hanusch, F. Democracy and Climate Change; Routledge: London, UK, 2018.

81. Deese, R.S. Climate Change and the Future of Democracy; Springer: Cham, Switzerland, 2019.

82. Campbell, G.S.; Campbell, D.F.J. The semi-aquatic theory: Semi-aquatic evolutionary phase and environment, language development of modern humans, with a short epilog on conceptualized evolution, social ecology and the Quintuple Helix. Int. J. Soc. Ecol. Sust. Dev. 2011, 2, 15-30. [CrossRef]

83. Obama, B. The irreversible momentum of clean energy. Science 2017, 355, 126-129. [CrossRef] [PubMed]

84. Freedom House Freedom in the World: Aggregate and Subcategory Scores; Freedom House: Washington, DC, USA, 2016; Available online: https: / / freedomhouse.org/report/freedom-world (accessed on 28 February 2021).

85. Freedom House Freedom of the Press: The Historical Freedom of the Press Data; Freedom House: Washington, DC, USA, 2016; Available online: https: / / freedomhouse.org/report-types/freedom-press (accessed on 28 February 2021).

86. World Bank Climate Change Knowledge Portal; World Bank: Washington, DC, USA, 2021; Available online: https:// climateknowledgeportal.worldbank.org/download-data (accessed on 28 February 2021).

87. Hsu, A.; Esty, D.; Levy, M.; de Sherbinin, A. The 2016 Environmental Performance Index Report; Yale Center for Environmental Law and Policy: New Haven, CT, USA, 2016. [CrossRef]

88. Yale Center for Environmental Law and Policy (YCELP, Yale University); Yale Data-Driven Environmental Solutions Group (Yale University); Center for International Earth Science Information Network (CIESIN, Columbia University). World Economic Forum (WEF) 2016 Environmental Performance Index (EPI); NASA Socioeconomic Data and Applications Center (SEDAC): Palisades, NY, USA, 2016; Available online: https:/ / sedac.ciesin.columbia.edu/data/set/epi-environmental-performance-index-2016/datadownload (accessed on 28 February 2021).

89. Simon, H. Spurious correlation: A causal interpretation. J. Am. Stat. Assoc. 1954, 49, 467-479.

90. Povitkina, M. The limits of democracy in tackling climate change. Environ. Polit. 2018, 27, 411-432. [CrossRef]

91. Dasgupta, S.; De Cian, E. The influence of institutions, governance, and public opinion on the environment: Synthesized findings from applied econometrics studies. Energ. Res. Soc. Sci. 2018, 42, 77-95. [CrossRef] 